\title{
The Association between Meaning in Life and Adherence to Antiretroviral Therapy (ART) of HIV-Seropositive within Men who have Sex with Men (MSM); Mixed Method
}

\author{
YafiSabila Rosyad $^{1}$, Hema Malini' ${ }^{2}$, Rika Sarfika ${ }^{2}$ \\ ${ }^{1}$ STIKes Yogyakarta Nursing lecturer, Daerah Istimewa Yogyakarta, ${ }^{2}$ Andalas University Nursing lecturer, \\ Padang West Sumatera, Indonesia
}

\begin{abstract}
Purpose: To identify the distribution of meaning in life frequency and adherence to antiretroviral therapy (ART) as well as to perceive and explore the association between meaning in life and adherence to antiretroviral therapy (ART) of HIV-seropositive within MSM in Padang City, West Sumatra, Indonesia.

Method: This research used a mixed method with an approach of exploratory sequence design, which was in quantitative stage through a cross-sectional design approach that intended to know the relationship between variables. 102 sample size. In the qualitative stage, the researchers used the conceptual content cognitive map (3CM) method as a data retrieval technique and then continued with the interview.

Results: Characteristics of MSM in West Sumatra more than half were gay with early adulthood who were mostly on ART treatment less than one year.Almost all MSM were middle and upper educated, and they worked in sixteen sectors of employment in which the private sector was the largest. Most MSM had a meaningful life. More than half of MSM were discipline to go through ART treatment. There was a significant correlation between the meaning in life and the adherence of ART $p(0,000)$ with the identification of several aspects that related to the meaning in life and ART adherence. They were spiritualism, lifestyle, psychological, life purpose, life achievement, knowledge, and motivation.
\end{abstract}

Conclusion: The importance of meaning in life within HIV-seropositive MSM that might influence the ART adherence. Therefore, the researchers recommendto conduct a compliance monitoring activity and provide logotherapy for MSM whose life is not meaningful.

Keywords: MSM, Meaning in life, ART adherence, HIV/AIDS, 3CM.

\section{Introduction}

The use of ARV requires a high adherence rate of $90-95 \%$ in order to achieve therapy success and can prevent the emergence of drug resistance ${ }^{(1,2)}$.WHO has a target that $90 \%$ of People Living with HIV/AIDS (PLWHA) already underwent ART by 2016, but the target realization is only 53\%. PLWHA who undergo antiretroviral therapy is increasing. In 2016, there are 19.5 million or about $53 \%$ of the total number of PLWHA, and in mid-June 2017 the number has progressed to 20.9 million or about $56.9 \%$ of the total number of PLWHA ${ }^{(3)}$. Meanwhile, PLWHA in Indonesia who have undergone ART based on Ministry of Health report (2016), in 2015 there were 63,066 people where 2,056 of them experienced ART on the second line, and by 2017, PLWHA who had accessed antiretroviral therapy were 77,780 people where 2,374 people were on ART on the second line. From the data above, we can conclude that there are still many PLWHA who have not accessed ART, while the number of PLWHA in the second line shows improvement from year to year ${ }^{(4)}$.

According to research by Audet, Wagner, \& Wallston (2015), meaningfulness of life by PLWHA associated with the psychological welfare of patients ${ }^{(5)}$. There has been no research on the relation of meaning in life toward ART, but based on research conducted by Corless et al.,(2006), about the relation of meaning in life to TB treatment adherence, it can conclude that 
there is a relationship between the meaning in life and the level of TB treatment adherence ${ }^{(6)}$. The meaning of life is a daily experience in life that is real $^{(7)}$ in both pleasant and unpleasant situations ${ }^{(8)}$ and if someone can live every event to meets then his life will be happy ${ }^{(9)}$. The feeling of happiness can be achieved if someone who can achieve his life goals ${ }^{(10)}$.

Researchers in preliminary study at NGOs Taratak Jiwa Hati with interview six participant find that all PLWHA are still difficult to remember to consume medicine and sometimes late to consume it and there are still MSM who feel their lives are meaningless. This study is important to undertake because it can give a description of ART adherence and the meaning in life of HIV-seropositive MSM. This study aims to identify the characteristics of HIV-seropositive Men who have sex with men (MSM), the distribution of meaning in life frequency and adherence to antiretroviral therapy (ART) as well as to perceive and explore the association พิ่ between meaning in life and adherence to antiretroviral therapy (ART) of HIV-seropositive within MSM in Padang City, West Sumatra, Indonesia.

\section{Material and Method}

This research was mixed method through explanatory sequel design approach, where the qualitative data that was obtained in the research will help the explanation of the quantitative data result ${ }^{(13)}$. In quantitative phase, researchers used a cross-sectional design ${ }^{(13)}$. Total sampling use in this research with 102 Sample size MSM with HIV at NGOs Taratak Jiwa Hati West Sumatra Indonesia.Before conducting the research, the researchers tested the validity and reliability of the Meaning in Life Questionnaire (MLQ)in Indonesian version $^{(14)}$ and Morisky- 8 Scale ${ }^{(15)}$ also in Indonesian version, and all question items of both questionnaires were valid and reliable ${ }^{(16,17)}$.In the qualitative phase, the researchers used The Conceptual Content Cognitive Map (3CM) method as a data retrieval technique. This method was a method developed by Kearny \& Kaplan, ${ }^{(18)}$ by using open-ended questions that were used to deeply understand the important concepts of informants' perceptions concerning the relationships between the meaning in life and ART adherence.

\section{Results and Discussion}

Research Sample: The characteristics of respondents including sexual orientation, age, education level, duration of ART, and occupation. More than half of the MSM were gay with early adulthood, a majority of them were on ART for less than one-year treatment, almost all MSM were middle and upper educated, and they worked in sixteen sectors of employment in which the private sector was the largest ${ }^{(19)}$. Based on research that the respondents who have sexual orientation as gay was 56 people and as bisexual men were 46 people. The age range of respondents was in the adulthood age between 25-45 years old, where this age range was for both early and late adulthood ${ }^{(4)}$. The education level of respondents, most of them, was in the middle and upper education with a percentage of $81.4 \%$. Various researches indicated that the level of education was one of the factors that will interact in health status. Where, if a person had a higher educational status, it could reduce mortality and increase the income, even reduce twice as much mortality either directly or indirectly ${ }^{(20,21)}$. In terms of time span on undergoing antiretroviral treatment, more than half or $54 \%$ of respondents were categorized as a newbie because it was still under one year time.

Meaning in life of HIV-seropositive MSM: The majority of respondents(64.71\%) had a meaningful life and about $35.29 \%$ felt a meaningless life of the 102 respondents, $72.5 \%$ felt that there was no distinct purpose in life, and almost all respondents(91.2\%) were looking for something that made their life meaningful.Meaning in life had a different function for each individual, but according to Mackenzie \& Baumeister (2014), the function of meaning in life could be divided into three function themes ${ }^{(22)}$. The meaning in life according toStarck(2014), was said to be the phase where a person reached his life goal ${ }^{(10)}$.According to Audet et al., (2015), the low meaning in life indicated non-adherence ART and provided a stimulus of management for handling the suffered disease ${ }^{(5)}$.We were able to analyze that most respondents had been able to find the meaning of their lives although the meaning in life that was found was from an unpleasant experience. The need for counseling to improve the meaningfulness of life of seropositive MSM (35.9\%). By doing so, MSM population especially seropositive one will get more external support or motivation and can improve their meaningfulness in life.

ART treatment adherence of HIV-seropositive MSM: From the research results obtained that 57.8\% respondents were adherence to antiretroviral therapy and the rest did not comply as much as 43 respondents or $42.2 \%$. This level of adherence was seen from the accuracy of the dosage and the frequency of timeconsuming ARV. According toBangsberg, Kroetz, \& 
Deeks, (2007), ART adherence should be observed to discern the compliance level of the treatment, as some studies indicate that with treatment adherence of $(95 \%)$ or more indicates the effectiveness of antiretroviral therapy ${ }^{(23)}$, but on adherence $(75 \%)$ shows a rise of viruses with retention against drugs ${ }^{(24)}$. Some patients fail to maintain ART adherence ${ }^{(25)}$.Treatment and handling management of HIV are part of the management of chronic diseases, which have principles of medication adherence, prevention of drug retention, and morbidity prevention management ${ }^{(25)}$. This condition becomes a challenge for health workers. Nurses can maximize counseling services particularly for HIV counselor and psychiatric nurses that can provide special therapies to turn negative behaviors into the positive. Apart from health workers, peer advocates also need to improve their role to remind the companions to take the drugs in a timely and appropriate dose given.

The relationship of meaning in life with ART adherence treatment within HIV-seropositive MSM

Table 1: The relationship of meaning in life with ART adherence treatment within HIV-seropositive MSM $\mathrm{n}=\mathbf{1 0 2}$

\begin{tabular}{|c|c|c|c|c|c|c|c|c|}
\hline \multirow{3}{*}{ Meaning in life } & \multicolumn{4}{|c|}{ ART adherence } & \multirow{2}{*}{\multicolumn{2}{|c|}{ Total }} & \multirow{3}{*}{$\mathbf{p}$} & \multirow{3}{*}{$\begin{array}{c}\text { OR } \\
(\mathrm{CI} 95 \%)\end{array}$} \\
\hline & \multicolumn{2}{|c|}{ Non-adherence } & \multicolumn{2}{|c|}{ Adherence } & & & & \\
\hline & f & $\%$ & $\mathbf{f}$ & $\%$ & $\mathbf{f}$ & $\%$ & & \\
\hline Meaningless & 31 & 86.1 & 5 & 13.9 & 36 & 100 & \multirow{2}{*}{0,000} & \multirow{2}{*}{$\begin{array}{c}27,90 \\
(8.98-86.82)\end{array}$} \\
\hline Meaningful & 12 & 18.8 & 54 & 81.8 & 66 & 100 & & \\
\hline
\end{tabular}

Table 1 showed that there was a relationship between meaning in life and ART adherence. When a person whose life was meaningless will have 27.90 times risk to be non-adherence in undergoing antiretroviral therapy than a person whose life was meaningful. The exploration results obtained 23 statements which consisted of 7 categories. The category are the purpose of life, the achievement of life, knowledge, motivation, spiritualism, lifestyle, and psychological.

Farber et al (2003), the meaning of the success of good treatment is directly proportional to the high expectation and inversely proportional to the level of depression ${ }^{(26)}$. There has been no research on the relation of the meaning in life to the level of ART adherence, but based on a research that conducted by Corless et al (2006), about the relation of meaning in life to TB treatment adherence, it can conclude that there is a relationship between the meaning in life and the level of TB treatment adherence ${ }^{(6)}$.

The exploration of the relationship between the meaning in life and ART adherence can occur due to the fulfillment of the basic components of the formation of meaning. According to Mackenzie \& Baumeister (2014), there are four basic components that form the meaning in life. First is the necessity for a purpose of life which can be categorized into results attainment and fulfillment of more abstract desire ${ }^{(22)}$. The exploration result from this life purpose component was that the participant had a life purpose to get married "... Although I am an LGBT, I have a plan to have a wife (P2)”.

The life accomplishing of each participant was unique and different in interpreting the achievement of their life. "...Can overcome all by thinking positively... experiencing the life...just like before HIV...(P1)”.

The other achievement of the meaning in life was always being motivated to experience the life "...Always keep the spirit, always optimistic and not pessimistic... (P3) " In addition, the participants also live his life by becoming a better person "...experiencing the life...by becoming a better person...(P4)”.

The next necessity is trust and faith. Participant's spirituality indicated the existence of belief or faith by placing his trust in God “...Pray regularly...ask God by tahajud prayer (Moslem's prayer near midnight), what is the crux of this problem so that it can be solved well (P3) ". Participants believed that by counseling their life purpose can be achieved, following the participant's statement;

"...According to the hospital, as a person with HIV, I can have a wife and have offspring without spreading the disease by doing the program (P2)"

The last necessity is that one must have positive self-esteem. The meaning in life according to Starck (2014), by having a sensitive feeling with the experience of how to love his life ${ }^{(10)}$. 
"...meet other people living with HIV.. feeling no burden of thinking and ... should be motivated in undergoing this antiretroviral therapy.. there is a desire to behave better again ... optimist to maintain health ... be firm in facing this life and keep struggling do not get desperate (P3)".

The freedom to choose what the participants did was to live a healthier life "...enough exercise, a good diet and have a deeper understanding of what HIV is (P2)". Human suffering is the third concept of the meaningful theory.

“..with despairing by not taking ARV (P3) and why doing a healthy life while I've HIV and no one willing to befriend me, to approach me...(P2)".

The uniqueness of a person's meaningful life that is stimulated by various things ultimately can make someone adherence to undergoing antiretroviral therapy. \% However, to gain meaningfulness of life, one must be The to accept who they are and where their position now. The meaningfulness of life can be obtained not only in 这 a pleasurable event but also be found from unpleasant events. HIV-seropositive is an unpleasant experience for everyone especially the respondents. Thus, health workers need to assist respondents in order to rediscover the purpose of their life so that they have the meaning in life as before HIV-seropositive.

\section{Conclusion}

PLWHA adherence to consume ART was influenced by the meaning in life, where, when PLWHA had a clear purpose that he wanted to accomplish in life, then that PLWHA will adherence to consuming ART. Meanwhile, PLWHA adherence was also influenced by peers, information attainment, and self-motivation. This research provides important suggestions for health workers to be actively involved in enhancing the motivation of PLWHA, especially MSM to behave openly so that the quality of life monitoring can be done.

Ethical Clearance: This study has passed and granted ethical clearance from the Faculty of Medicine University of Andalas No.346/KEP/FK/ 2018.

Source of Funding: Self-funding

Conflict of Interest: None

\section{Reference}

1. Depkes. Pedoman Pelayanan Kefarmasian Untuk Orang Dengan HIV/AIDS (ODHA). Jakarta: Direktorak Bina Farmasi Komunitas dan Klinik DITJEN Bina Kefarmasian dan ALat Kesehatan; 2006.

2. Hastuti E, Nugrahini N, Subroto Y, Dzoerban Z, Djauzi S, Hastuti E, et al. Pedoman Nasional Tatalaksana Klinins Infeksi HIV dan Terapi Antiretroviral Pada Orang Dewasa. Subroto Y, Budiarto, Pulungsih S, Lingga J, Hastuti E, Prameswar H, et al., editors. Jakarta: Kementerian Kesehatan RI; 2011.

3. WHO. World Health Statistics 2017 Monitoring Health For the SGDs [Internet]. France: WHO Press; 2017. 1-103 p. Available from: http://apps. who.it/iris

4. Kemenkes. Profil Kesehatan Indonesia Tahun 2016. Jakarta: Kementerian Kesehatan RI; 2017.

5. Audet CM, Wagner LJ, Wallston KA. Finding meaning in life while living with HIV : validation of a novel HIV meaningfulness scale among HIVinfected participants living in Tennessee. BMC Psychol [Internet]. 2015;3(15):1-8. Available from: ???

6. Corless IB, Nicholas PK, Wantland D, McInerney $\mathrm{P}, \mathrm{Ncama} \mathrm{B}, \mathrm{Bhengu} \mathrm{B}$, et al. The impact of meaning in life and life goals on adherence to a tuberculosis medication regimen in South Africa. Int J Tuberc Lung Dis. 2006;10(10):1159-65.

7. Bastaman HD. Logoterapi: Psikologi untuk menentukan makna hidup dan meraih hidup bermakna. Jakarta: Raya Grafindo Pusada; 2007.

8. Schultz D. Psikologi Pertumbuhan: Model-model Psikologi Sehat. Yogyakarta: Kanisius; 1997.

9. Purba R. Prosen pencarian makna hidup pada ODHA (Orang dengan HIV/AIDS). Universitas Katolik Soegijapranata Semarang; 2008.

10. Starck PL. Theory of Meaning. In: Middle Rage Theory for Nursing. Third Edit. New York: Springer Publishing Company, LLC; 2014. p. 87-108.

11. Creswell J. Research design Pendekatan metode kuantatif, kualitatif, dan campuran. 1st ed. Yogyakarta: Pustaka Pelajar; 2016. 
12. Teddie C, Tashakkori A. Foundations of Mixed Method Research: Integrating quantitative and Qualitative Approache in the Social and Behavioral Sciences. I. California: SAGE Publications; 2009.

13. Sugiono. Metode Penelitian Kuantitatif, Kualitatif, dan R\&D. 23rd ed. Bandung: Alvabeda; 2016.

14. Steger M, Frazier P, Oishi S, Kaler M. The meaning in life questionnaire: Assessing the presence of and search for meaning in life. $\mathrm{J}$ Couns Psychol [Internet]. 2006;53(1):80-93. Available from: http://doi.apa.org/getdoi.cfm?d oi $=10.1037 / 0022-0167.53 .1 .80$

15. Morisky DE, Green LW, Levine DM. Concurrent and Predictive validity of a self-reported measure of medication adherence. Med Care. 1986;24:6774.

16. Rosyad YS, Malini H, Sarfika R. Validity and reliability the meaning in life questionnaire (MLQ); Men who have sex with men at west Sumatera Indonesia. Ris Inf Kesehat. 2019;8(1):16-21.

7. Rosyad YS. Hubungan efikasi diri dan makna hidup dengan kepatuhan pengobatan antiretroviral therapy (ART) pada lelaki seks lelaki seropositif HIV di Yayasan Teratak Jiwa Sumatera Barat [Internet]. Universitas Andalas; 2018. Available from: http:// scholar.unand.ac.id/id/eprint/34988\%0A

18. Kearney AR, Kaplan S. Toward a methodology for the of knowledge structures of ordinary people: The Conceptual Content Cognitive Map (3CM). Environ Behav. 1997;579-617.

19. Rosyad YS. Characteristic men who love sex with men HIV+ in GOs Taratak Jiwa hati West Sumaera Indonesia. Paeipex Indian Joaurnal Res. 2018;7(8):144-5.
20. Pampel FC, Krueger P, Denney J. socioeconomic Disparities in Health Behaviors. Annu Rev Sociol [Internet]. 2010;36:349-70. Available from: http://www.ncbi.nlm.nih.gov/pmc/articles/ PMC3169799/

21. Speake DL, Cowart ME, Pellet K. Health perceptions and lifestyles of the elderly. Res Nurs Health. 1989;12(2):93-100.

22. Batthyany A, Netzer PR. Meaning in Life : Nature , Needs, and Myths. In: Meaning in positive and existensial psychology [Internet]. XVII. New York: Spinger Science+Business Media New York; 2014. p. 25-37. Available from: http://www.springer. com/9781493903078

23. Bangsberg DR, Kroetz DL, Deeks SG. Adherenceresistance Relationships to Combination HIV Antiretroviral Therapy. Curr HIV/AIDS Rep. 2007;(4):65-72.

24. Bangsberg DR. Less Than $95 \%$ Adherence to Nonnucleoside Reverse-Transcriptase Inhibitor Therapy Can Lead to Viral Suppression [Internet]. Vol. 43. 2006. Available from: http://cid. oxfordjournals.org/

25. Mukumbang FC, Belle S Van, Marchal B, Wyk B Van. Exploring ' generative mechanisms' of the antiretroviral adherence club intervention using the realist approach : a scoping review of researchbased antiretroviral treatment adherence theories. BMC Public Health. 2017;1-14.

26. FarberEw, Mirsalimi H, Williams Ka, McDanielJS. Meaning of Illness and Psychological Adjustment to HIV / AIDS. Psychomatics. 2003;44(6):485-91. 